This item was submitted to Loughborough's Research Repository by the author.

Items in Figshare are protected by copyright, with all rights reserved, unless otherwise indicated.

\title{
Safety risk assessment for vertical concrete formwork activities in civil engineering construction
}

PLEASE CITE THE PUBLISHED VERSION

http://dx.doi.org/10.3233/WOR-131724

PUBLISHER

(C) IOS Press

VERSION

AM (Accepted Manuscript)

\section{PUBLISHER STATEMENT}

This work is made available according to the conditions of the Creative Commons Attribution-NonCommercialNoDerivatives 4.0 International (CC BY-NC-ND 4.0) licence. Full details of this licence are available at: https://creativecommons.org/licenses/by-nc-nd/4.0/

\section{LICENCE}

CC BY-NC-ND 4.0

\section{REPOSITORY RECORD}

Lopez-Arquillos, A., Juan C. Rubio-Romero, Alistair G.F. Gibb, and J.A. Gambatese. 2019. "Safety Risk Assessment for Vertical Concrete Formwork Activities in Civil Engineering Construction”. figshare. https://hdl.handle.net/2134/18081. 


\title{
SAFETY RISK ASSESSMENT FOR VERTICAL CONCRETE FORMWORK
}

\section{ACTIVITIES IN CIVIL ENGINEERING CONSTRUCTION.}

\author{
Lopez-Arquillos, A; Rubio-Romero, JC; Gibb, AGF; Gambatese, JA (2014)
}

Work: A Journal of Prevention, Assessment \& Rehabilitation, 49:2, 183-192,

ISSN 1051-9815, DOI 10.3233/WOR-131724

\begin{abstract}
:
BACKGROUND: The construction sector has one of the worst occupational health and safety records in Europe. Of all construction tasks, formwork activities are associated with a high frequency of accidents and injuries.
\end{abstract}

OBJECTIVE: This paper presents an investigation of the activities and related safety risks present in vertical formwork for in-situ concrete construction in the civil engineering sector. METHODS: Using the methodology of staticized groups, twelve activities and ten safety risks were identified and validated by experts. Every safety risk identified in this manner was quantified for each activity using binary methodology according to the frequency and severity scales developed in prior research. A panel of experts was selected according to the relevant literature on staticized groups.

RESULTS: The results obtained show that the activities with the highest risk in vertical formwork tasks are: Plumbing and leveling of forms, cutting of material, handling materials with cranes, and climbing or descending ladders. The most dangerous health and safety risks detected were falls from height, cutting and overexertion.

CONCLUSIONS The research findings provide construction practitioners with further evidence of the hazardous activities associated with concrete formwork construction and a starting point for targeting worker health and safety programmes.

Keywords: Occupational, expert panel, fall from height,

\section{Introduction}

According to the European Agency for Safety and Health at Work, the construction sector has one of the worst occupational health and safety records in Europe [1]. In the original 15 European Union (EU) Member States alone, about 1,300 construction workers die every year, another 800,000 are injured, and countless more suffer work-related ill health [2].

In the United States, 751 deaths occurred on construction sites in 2010 [3]. This figure accounts for about $17 \%$ of all fatal occupational injuries and is the fourth highest fatality rate for all U.S. industries. A similar problem exists in Spain where the fatality rate on construction sites in 2011 was 11.2 fatalities per 100,000 workers [4], with a total of 120 worker deaths.

Formwork is defined as a temporary structure whose purpose is to provide support and containment for fresh concrete until it can support itself. It molds the concrete to the desired shape and size, and controls its position and alignment [5].Of all construction tasks, formwork activities are associated with a high frequency of accidents and injuries. Huang and Hinze [6] observed that $5.83 \%$ of falls were attributed to the construction of formwork or to the 
construction of temporary structures and approximately $21 \%$ of all accidents involved wood framing or formwork construction. Many studies on construction safety are focused on topics such as contributing factors in construction accidents [7] or the impact of the different variables on the severity of the accidents $[8,9,10,11,12,13,14,15]$. Research studies have tried to quantify the safety risks of large-scale processes, such as underground construction projects [16] or buildings [17]. However, only one study was found in which the authors actually quantified the relative health and safety risks of specific construction tasks [18]. The objective of the latter study was to quantify the comprehensive health and safety risk at the activity level for a common construction process, such as formwork activities, using the Delphi method.

The aim of the present study is to quantify the health and safety risks in different vertical formwork activities in civil engineering construction using the binary method and the methodology of staticized groups.

\section{Methodology}

To achieve the study aim, the researchers used two different methodologies. A general research methodology was used to define the study's structure and a specific methodology inside this structure was used as a tool to elaborate the safety risk assessment.

With regard to the specific methodology, some authors have developed methods of risk quantification with different levels of complexity and application. An example of this is a study where ergonomic risks were analysed using ratings for each risk factor on a three-point scale [insignificant, moderate and high] in 65 construction activities to identify the presence of risk factors concerning overexertion injuries [19]. Other studies quantifying safety risk defined it as the product of frequency and severity [20]. A similar methodology with the addition of the exposure factor was used by Jannadi and Almishari [21].The method we have chosen for this study is the approach known as the binary method [22], where the unit risk is defined as the product of frequency and severity (see Equation 1).Frequency is defined in terms of worker hours per incident, while severity is defined in terms of impact on the worker per incident.

$$
\text { UNIT RISK }\left(\frac{\text { severity }}{\text { work-hour }}\right)=\text { Frequency }\left(\frac{\text { incident }}{\text { work-hour }}\right) \times \text { Severity }\left(\frac{\text { severity }}{\text { incident }}\right)(1)
$$

Once the method for risk quantification was defined, the next step was to define a suitable research strategy to accomplish our specific goal.

According to a previous civil construction research [23] based on the Delphi method, cited method can be defined as systematic and interactive research technique for obtaining the judgment of a panel of independent experts on a specific topic. Panel members are selected according to predefined guidelines and are asked to participate in two or more rounds of structured surveys. After each round, an anonymous summary of the experts' input from the previous survey is provided as a part of the subsequent survey. In each subsequent round, participants are encouraged to review the anonymous opinion of the other panelists and consider revising their previous response. The goal during this process is to decrease the variability of the responses and achieve group consensus about a correct value. Finally, the process is concluded after a predefined criterion (as number of rounds or the achievement of consensus) is met and a statistical aggregation of the responses in the final round determines the results.

The staticized group technique is very similar to the Delphi method. The only methodological difference is the exclusion of feedback or iterations in the staticized group technique. Several studies have reported different opinions about the accuracy of both methods. Some of these studies have reported a significant increase of the staticized group technique over Delphi rounds as far as accuracy is concerned [24, 25]. By contrast, other studies found no substantial difference in the accuracy records when the Delphi and staticized group approaches were 
compared [26, 27]. Meanwhile, two other surveys suggested that the accuracy of the Delphi method is worse when there is a high level of iterations [28, 29].

Authors such as Erffmeyer and Lane [30] are in favour of using the staticized group approach because panel members are not led to achieve a consensus on a value that could be wrong. This is the main reason why the present study was carried out using the method of staticized groups.

\subsection{Panel Members}

As in the Delphi procedure, in the staticized group approach the selection of experts is a very important factor in determining the quality of the study. Hallowell and Gambatese [23] maintain that the level of expertise is the most important facet in a panel member and propose guidelines for a flexible point system for the selection of an expert panel member. A suitable adaptation of the suggested point system to the specific goals of our research project resulted in the requirements listed in Table 1.

The authors contacted 15 construction companies and 10 universities. After a review of the background and availability of the possible candidates, 12 experts were selected from 7 large high profile companies from the engineering construction sector, and from 5 Schools of Engineering. In addition to the flexible point system requirements, only one expert per company or per University was selected in order to ensure diversity in the origin of the experts.

According to the guidelines proposed by Hallowell and Gambatese [23], all members of the panel met the minimum level of requirements. As can be seen in Table 2, all of the panellists scored a total of at least 17 points and in at least four different achievement or experience categories. Four other professionals were selected as panel members, but they did not complete the survey and so were excluded from the final list of panel members and also from the results shown in Table 2.

TABLE 2

The qualifications of the selected members of the staticized groups are as follows.

\subsection{Study Design}

A web-survey used for collecting the expert responses was developed on a specialized site and was made available to the experts. Experts had access to the survey only by using a password supplied by the researchers. The web-survey expired after the collection of data in the above mentioned period of time. 
In order to improve the quality of the study, certain strategies for study design and the elimination of bias were adopted. For example:

- The order of the questions and the order of the potential safety risk in the survey were randomized for each panel member to reduce the contrast effect and the primacy effect.

- Independent frequency and severity rates were implemented.

- The anonymity of each expert was ensured.

\subsection{Survey Content}

Following the guidelines of Hallowell and Gambatese [18], experts were provided with the incident classification descriptions (Table 3) and the formwork construction activity descriptions (Table 4). In line with the above, the selected incidents or health and safety risk classification were based on the Occupational Safety \& Health Administration, Bureau of Labour Statistics, and Hinze accident classification systems [31].

The panellists were asked to provide their opinion on frequency rates and severity levels using the frequency and severity scales provided previously (Table 5\&Table 6). These scales were created by Hallowell and Gambatese [18], and cover a complete spectrum of frequency and severity levels.

TABLES 3-6

\section{Results and Discussion}

Although consensus is not a requirement for the methodology of staticized groups, it was also calculated in order to compare the results with the Delphi approach (Table 7).

To measure the variation in the responses, the absolute deviation was calculated using the following equation:

$$
\text { Average Deviation from Median = Average }(\text { Median } \mathrm{j}-\text { Value ij })(2)
$$

After calculating the absolute deviation from the median, and accepting that consensus is achieved with a value less than $1 / 10$ of the possible value for the quantitative study developed, the target consensus was found to be achieved in this case.

167 Table 8 shows the quantified risk when all formwork activities are included by the following

168 methods. First, the frequency ratings chosen by the expert from a range of values from table 5 with units of worker-hours per incident were converted into a single point value with units of incidents per worker-hour. Then single point values were multiplied by the severity values chosen by the experts according to the severity scale from Table 6.

\section{TABLE 8}

173 For example, if the expert rated the average frequency as $10-100 \mathrm{w}$-h /incident, the mean value 174 of $55 \mathrm{w}$-h/incident was identified in order to convert to a single value, and the inverted value 1750.018 [1/55] represented the frequency value for the particular risk and activity. The product of 176 this frequency and the severity rating from table 6 represents the unit risk for the activities.

177 In a further analysis of the data matrix shown in Table 8, two different comparative tables were 178 produced according to the sum values from a row [Activities] and from a column [Safety risks].

179 Table 9 summarizes the total safety risk score for each activity, and Table 10 shows the 180 quantified risks when all formwork activities are included.

\section{TABLE 9}

182 Table 9 shows that the highest risk scores for the construction activities under study were obtained by the activities plumb/level forms $(0.4772 \mathrm{~S} / \mathrm{w}-\mathrm{h})$ cut material $(0.0585 \mathrm{~S} / \mathrm{w}-\mathrm{h})$, crane 
material $(0.0194 \mathrm{~S} / \mathrm{w}-\mathrm{h})$ and ascend/descend ladder $(0.0187 \mathrm{~S} / \mathrm{w}-\mathrm{h})$. On the other hand, the lowest risk scores were obtained by lubrication/preparation $(0.0008 \mathrm{~S} / \mathrm{w}-\mathrm{h})$, manual transport $(0.0006 \mathrm{~S} / \mathrm{w}-\mathrm{h})$ and inspect/plan $(0.0002 \mathrm{~S} / \mathrm{w}-\mathrm{h})$. Some of the activities with the highest risk scores such as crane material or ascend and descend ladders, have been dealt with in other papers with a more general approach $[32,33,34,35,36]$. Our specific results for vertical formwork activities in construction are in line with other general results that are discussed below.

Surprisingly, the first and second highest risk score activities, that is, plumb/level forms and cut material, had not been studied before. This fact could be due to the highly specific activities involved. Consequently, further research concerning these issues is needed. It is especially significant that plumb/level forms accumulated approximately $80 \%$ of all of the risk. Therefore, it should be an activity which is the primary focus of safety management on the worksite.

Crane-lifting of material is one of the major causes of fatalities in construction [32]. To reduce the rate of crane fatalities, these authors believe that crane operators and riggers should be qualified and requalification courses should take place every 3 years. Likewise, other researchers [33] highlighted the fact that big contractors and other agents provide insufficient training for crew members. In addition, these authors found difficulties in communication among crew members, including language and a proper understanding of signals. Consequently, to improve the health and safety levels in these tasks, education programmes should be redesigned for all workers engaged in crane operations. Sometimes the risk is caused by deficiencies in the electrical system of the crane [34].

Ascending and descending ladders has been associated with a high percentage (33.5\%) of the non-fatal accidents in construction workers in the United States [35]. Ladders were also associated with $11 \%$ of all fatal falls over the period 1980-1989 in the US. More recently, ladder-related accidents have been shown to be associated with risk factors that increased the probability of a serious or fatal accident [36]. Hallowell and Gambatese [18] found that this activity is one of the most dangerous. They studied formwork activities following a more general approach, that is, without concentrating on vertical civil works. To improve the safety records at work in this activity, we must make a more accurate risk assessment.

Regarding the health and safety risk values included in Table 10, the highest risk scores were obtained by fall to a lower level $(0.5247 \mathrm{~S} / \mathrm{w}-\mathrm{h})$, cutting $(0.0591 \mathrm{~S} / \mathrm{w}-\mathrm{h})$ and overexertion $(0.0079 \mathrm{~S} / \mathrm{w}-\mathrm{h})$. The lowest risk scores correspond to fall on the same level $(0.0001 \mathrm{~S} / \mathrm{w}-\mathrm{h})$, exposure to harmful substances $(0.0000 \mathrm{~S} / \mathrm{w}-\mathrm{h})$ and others $(0.0000 \mathrm{~S} / \mathrm{w}-\mathrm{h})$. The health and safety risks studied had previously been addressed by many papers on construction activities $[18,19,37,38,39,40,41]$. The results provided here on specific vertical formwork safety risks are in line with the results of other general studies on the same issue.

Given their fatal consequences, falls to a lower level in the construction industry have been extensively studied by many authors [35, 36, 37, 38, 39]. Although these authors studied falls in the construction industry, their research was not focused on falls related to a formwork task. The most relevant work on falls and formwork is the study carried out by Adam, Pallarés, and Calderon [41]. In this study, falls from a height during floor slab formwork of buildings are dealt with specifically. They compared the fall protection systems commonly used during floor slab formwork construction in buildings and concluded that the suitability of the different systems depends greatly on the willingness of the workers to use the systems. This fact should be taken into account when making the choice. Hallowell and Gambatese [18] found that falls to a lower level is a very important risk, but this result was obtained without distinguishing between the two types of formwork (vertical or horizontal).Unfortunately, no literature about the risk of falls in vertical formwork in civil engineering is available. In a similar way to the studied activities, fall to lower levels accumulated almost $88 \%$ of the total risk score. Therefore concentration on this aspect of the work will produce the greatest improvement in health and safety performance. 
Overexertion injury is the single largest category of injuries in construction work. They account for about 24\% of all injuries [19]. Everett's analysis shows that virtually all construction activities have moderate-to-high ratings for at least one risk factor, and thereby place craft workers at increased risk for overexertion injuries and disorders.

The authors of this paper have found no articles on the safety risk involved in formwork cutting activities.

To sum up, although there are several research papers on common health and safety issues in construction work, there is still a significant shortage of specific investigations on some of the activities and risks relating to tasks such as formwork erection dealt with in this paper.

\section{Conclusions}

The results of this study can be used as an important tool for making a risk assessment when a vertical formwork task is scheduled. Each construction project involves specific health and safety issues because each has different circumstances and environment. However, the general health and safety topics described in this research can be addressed effectively on each project.

As for preventive measures, resources are always limited and must be managed efficiently. Construction practitioners must first identify the most dangerous activities and their safety risks. This is the first step for prioritizing preventive measures according to a suitable scale of needs. The classification obtained according to the scores provided by expert panel members in this study placed plumb/level forms, cut material, crane-lift material, and ascend/descend ladder at the top of the list of activities with high risk factors. Likewise, fall to a lower level, cutting, and overexertion were the most dangerous safety risks according to the experts. Accordingly, special attention is needed to reduce these safety risks.

\subsection{Limitations of the study}

This research does not consider the exposure [worker-hours] to the hazards. The total risk will depend on the magnitude of the exposure [see Equation 3]. The exposure can vary significantly depending on the specific construction project.

TOTAL RISK $($ severity $)=$ Frequency $\left(\frac{\text { accident }}{\text { work-hour }}\right) \times$ Severity $\left(\frac{\text { severity }}{\text { accident }}\right) \times$ Exposure $($ work-hour $)(3)$

If the exposure is high but the unit risk is low, then the total risk may be high relative to the other activities. Similarly, if the exposure is low, but the unit risk is high, then the total risk may be low compared to the other activities. In spite of this fact, unit risk is a very important tool to quantify health and safety needs.

The results allow us to compare risk values between different activities, and valuate them in order to prioritize preventive resources. However, as a relative subjective scale, it cannot be said that greater than a specific value the risk is major and under this value the risk is minor.

\subsection{Impact on the Industry}

The conclusions from this research can be used by construction companies in several ways. Health and Safety managers and supervisors can improve associated risks with specific activities, especially with plumb/level forms activities and risks of falls to lower levels. Project engineers and designers can estimate the exposure time for their specific project and calculate the total risk. This calculation can be made considering the different formwork types and design solutions. Companies can use the results obtained in their occupational safety strategies and in their safety training programmes. The authors encourage further research on the issue and promote future solutions to prevent the risks involved. 


\section{ACKNOWLEDGMENTS}

285 [edited for the review process]

\section{REFERENCES}

288 [1] OHSA Europe. European Agency for Safety and Health at Work. Building in Safety 289 Prevention of risks in construction - in practice. : Office for Official Publications of the 290 European Communities 2004; 2004.

291 [2] OHSA Europe. European Agency for Safety and Health at Work. 292 http://osha.europa.eu/en/sector/construction. 2012.

293 [3] BLS. Bureau of Labor Statistics.National census of fatal occupational injuries in 2010 294 [preliminary results].http://www.bls.gov/news.release/archives/cfoi 08252011.pdf. 2010.

295 [4] INSHT. Instituto Nacional de Seguridad e Higiene en el Trabajo. Avance de siniestralidad 296 laboral. Periodo octubre 2010-septiembre 2011. ; 2011.

297 [5] Hanna AS. Concrete formwork systems. : CRC; 1998.

298 [6] Huang X, Hinze J. Analysis of construction worker fall accidents. J Constr Eng Manage 299 2003;129[3]:262-271.

300 [7] Haslam R, Hide S, Gibb AGF, Gyi DE, Pavitt T, Atkinson S, et al. Contributing factors in 301 construction accidents. Appl Ergon 2005;36[4]:401-415.

302 [8] Sawacha E, Naoum S, Fong D. Factors affecting safety performance on construction sites. 303 Int J Project Manage 1999;17[5]:309-315.

304 [9] Salminen S. Have young workers more injuries than older ones? An international literature 305 review. J Saf Res 2004;35[5]:513-521.

306 [10] Chau N, Gauchard GC, Siegfried C, Benamghar L, Dangelzer JL, Francais M, et al. 307 Relationships of job, age, and life conditions with the causes and severity of occupational 308 injuries in construction workers. Int Arch Occup Environ Health 2004;77[1]:60-66.

309 [11] LópezArquillos A, Rubio Romero JC, Gibb A. Analysis of construction accidents in Spain, 310 2003-2008. J Saf Res 2012.

311 [12] Choi SD. Safety and ergonomic considerations for an aging workforce in the US 312 construction industry. Work: A Journal of Prevention, Assessment and Rehabilitation 313 2009;33(3):307-315.

314 [13] Goldsheyder D, Weiner SS, Nordin M, Hiebert R. Musculoskeletal symptom survey among 315 cement and concrete workers. Work: A Journal of Prevention, Assessment and Rehabilitation 316 2004;23(2):111-121.

317 [14] Gillen M, Kools S, Sum J, McCall C, Moulden K. Construction workers' perceptions of 318 management safety practices: A qualitative investigation. Work: A Journal of Prevention, 319 Assessment and Rehabilitation 2004;23(3):245-256.

320 [15] Liu M, Wei W, Fergenbaum J, Comper P, Colantonio A. Work-related mild-moderate 321 traumatic brain injury and the construction industry. Work: A Journal of Prevention, 322 Assessment and Rehabilitation 2011;39(3):283-290.

323 [16] Choi HH, Cho HN, Seo J. Risk assessment methodology for underground construction 324 projects. J Constr Eng Manage 2004;130[2]:258-272.

325 [17] Aneziris O, Topali E, Papazoglou I. Occupational Risk of building construction. Reliab 326 Eng Syst Saf 2011. 
[18] Hallowell MR, Gambatese JA. Activity-based safety risk quantification for concrete formwork construction. J Constr Eng Manage 2009;135[10]:990-998.

[19] Everett JG. Overexertion injuries in construction. J Constr Eng Manage 1999;125[2]:109114.

[20] Sun Y, Fang D, Wang S, Dai M, Lv X. Safety risk identification and assessment for Beijing Olympic venues construction. J Manage Eng 2008;24[1]:40-47.

[21] Jannadi OA, Almishari S. Risk assessment in construction. J Constr Eng Manage 2003;129[5]:492-500.

[22] Romero JCR. Métodos de evaluación de riesgos laborales. : Ediciones Díaz de Santos; 2004.

337 [23] Hallowell MR, Gambatese JA. Qualitative research: application of the Delphi method to CEM research. J Constr Eng Manage 2009;136[1]:99-107.

[24] Best RJ. An experiment in Delphi estimation in marketing decision making. J Market Res 1974:448-452.

[25] Rowe G, Wright G. The impact of task characteristics on the performance of structured group forecasting techniques. Int J Forecast 1996;12[1]:73-89.

[26] Fischer GW. When oracles fail -A comparison of four procedures for aggregating subjective probability forecasts. Organ Behav Hum Perform 1981;28[1]:96-110.

[27] Sniezek JA. A comparison of techniques for judgmental forecasting by groups with common information. Group \& Organization Management 1990;15[1]:5-19.

347 [28] Gustafson DH, Shukla RK, Delbecq A, Walster GW. A comparative study of differences in

348 subjective likelihood estimates made by individuals, interacting groups, Delphi groups, and nominal groups. Organ Behav Hum Perform 1973;9[2]:280-291.

350 [29] Boje DM, Murnighan JK. Group confidence pressures in iterative decisions. Management 351 Science 1982;28[10]:1187-1196.

352 [30] Erffmeyer RC, Lane IM. Quality and acceptance of an evaluative task: The effects of four group decision-making formats. Group \& Organization Management 1984;9[4]:509-529.

354 [31] Hinze J. Construction safety. : Prentice-Hall Upper Saddle River, NJ; 1997.

[32] Beavers J, Moore J, Rinehart R, Schriver W. Crane-related fatalities in the construction industry. J Constr Eng Manage 2006;132[9]:901-910.

357 [33] Tam VWY, Fung IWH. Tower crane safety in the construction industry: A Hong Kong 358 study. Saf Sci 2011;49[2]:208-215.

359 [34] Rubio-Romero JC, Simón-Donaire JM. Principales defectos en las instalaciones eléctricas 360 de las grúas torre desmontables para obra. Dyna, 2009: 84[4]:321-326.

361 [35]Cattledge GH, Hendricks S, Stanevich R. Fatal occupational falls in the US construction industry, 1980-1989. AccidentAnalysis\&Prevention 1996;28[5]:647-654.

363 [36] Camino López MA, Ritzel DO, Fontaneda González I, González Alcántara OJ. 364 Occupational accidents with ladders in Spain: Risk factors. J Saf Res 2011.

365 [37] Derr J, Forst L, Chen HY, Conroy L. Fatal falls in the US construction industry, 1990 to 366 1999. Journal of occupational and environmental medicine 2001;43[10]:853-860.

367 [38] Dong XS, Fujimoto A, Ringen K, Men Y. Fatal falls among Hispanic construction workers. 368 Accident Analysis \& Prevention 2009;41[5]:1047-1052.

369 [39] Gillen M. Injuries from construction falls. Functional limitations and return to work. 370 AAOHN journal: official journal of the American Association of Occupational Health Nurses 371 1999;47[2]:65. 
[40] Cattledge GH, Schneiderman A, Stanevich R, Hendricks S, Greenwood J. Nonfatal occupational fall injuries in the West Virginia construction industry. Accident Analysis \& Prevention 1996;28[5]:655-663.

375 [41] Adam JM, Pallarés FJ, Calderón PA. Falls from height during the floor slab formwork of buildings: Current situation in Spain. J Saf Res 2009;40[4]:293-299.

TABLES.

380 Table 1.Flexible point system for the selection of panel members.

\begin{tabular}{|l|c|}
\hline Achievements or experience & Points \\
\hline Master of Science in Occupational Risk Prevention & 5 \\
\hline Technical Degree [Architect or Engineer ] & 4 \\
\hline Years of professional experience & 1 per year \\
\hline Professional registration & 2 \\
\hline Author of a book on safety & 2 per book \\
\hline Author of an article on safety in a learned journal & 2 per article \\
\hline Faculty member at an accredited university & 3 \\
\hline Ph.D. & 4 \\
\hline
\end{tabular}


Table 2. Panel members’ scores

\begin{tabular}{|l|c|c|c|c|c|c|c|c|c|c|}
\hline $\begin{array}{c}\text { Panel } \\
\text { Member }\end{array}$ & $\begin{array}{c}\text { Master of } \\
\text { Science in } \\
\text { Occupational } \\
\text { Risk Prevention }\end{array}$ & $\begin{array}{c}\text { Technical } \\
\text { Degree }\end{array}$ & $\begin{array}{c}\text { Years of } \\
\text { experience }\end{array}$ & $\begin{array}{c}\text { Professional } \\
\text { registration }\end{array}$ & $\begin{array}{c}\text { Author of } \\
\text { a book on } \\
\text { safety }\end{array}$ & $\begin{array}{c}\text { Author of } \\
\text { an article } \\
\text { on safety in } \\
\text { learned } \\
\text { journal }\end{array}$ & $\begin{array}{c}\text { Faculty } \\
\text { member at } \\
\text { and } \\
\text { accredited } \\
\text { university }\end{array}$ & $\begin{array}{c}\text { PhD } \\
\text { Total } \\
\text { Points } \\
\text { achievement } \\
\text { categories }\end{array}$ \\
\hline Expert 1 & 5 & 4 & 18 & 2 & 32 & 22 & 3 & 4 & 90 & 8 \\
\hline Expert 2 & 5 & 4 & 23 & 0 & 0 & 4 & 3 & 0 & 39 & 5 \\
\hline Expert 3 & 5 & 4 & 12 & 0 & 4 & 12 & 0 & 0 & 37 & 5 \\
\hline Expert 4 & 5 & 4 & 10 & 2 & 4 & 0 & 0 & 0 & 25 & 5 \\
\hline Expert 5 & 5 & 4 & 13 & 2 & 0 & 0 & 0 & 0 & 24 & 5 \\
\hline Expert 6 & 5 & 4 & 0 & 0 & 8 & 0 & 3 & 4 & 24 & 5 \\
\hline Expert 7 & 5 & 4 & 12 & 2 & 0 & 0 & 0 & 0 & 23 \\
\hline Expert 8 & 5 & 4 & 6 & 2 & 0 & 0 & 0 & 0 & 17 \\
\hline TOTAL & 40 & 32 & 94 & 10 & 48 & 38 & 9 & 8 & 279 \\
\hline Average & 5.0 & 4.0 & 11.8 & 1.3 & 6.0 & 4.8 & 1.1 & 1.0 & 34.9 \\
\hline
\end{tabular}


Table 3.Incident classification

Exposure to harmful substances

Fall to lower level

Fall onthe same level

Cutting

Overexertion

Struck against objects in motion

Struck against objects

Caught in or compressed

Repetitive motion

Others 
Table 4. Activities

\begin{tabular}{|l|l|}
\hline Activity name & Description \\
\hline Ascend /descend ladder & $\begin{array}{l}\text { Ascending or descending ladders to reach the workface at } \\
\text { different levels from the ground. }\end{array}$ \\
\hline Lift /lower materials & $\begin{array}{l}\text { Lifting or lowering materials or equipment from/to ground } \\
\text { level. }\end{array}$ \\
\hline Nail/screw/drill & $\begin{array}{l}\text { Nailing, screwing or drilling formwork components using } \\
\text { hammer, nail gun or similar. }\end{array}$ \\
\hline Hammer materials & $\begin{array}{l}\text { Hammer or drive large objects with tools such as a } \\
\text { sledgehammer. }\end{array}$ \\
\hline $\begin{array}{l}\text { Crane materials and } \\
\text { motorized transport }\end{array}$ & $\begin{array}{l}\text { Materials or formwork components are transported by cranes } \\
\text { or by vehicles such as trucks, skid steers or scissor lifts. } \\
\text { Including loading operations. }\end{array}$ \\
\hline Cut materials & $\begin{array}{l}\text { Formwork operations where plywood or aluminium is cut on- } \\
\text { site. }\end{array}$ \\
\hline Inspect/plan & $\begin{array}{l}\text { Workers, supervisors and managers of construction planning } \\
\text { and inspecting the works. }\end{array}$ \\
\hline Manual transport & Transporting equipment and materials. \\
\hline Static lift & $\begin{array}{l}\text { Supporting a portion of formwork while other workers } \\
\text { connect components or materials. }\end{array}$ \\
\hline Elumb/level forms & $\begin{array}{l}\text { Fevelling and plumbing forms to shift and adjust a form. } \\
\text { form with oil and/or curing compound and setting and wetting } \\
\text { curing blankets and expansion materials. }\end{array}$ \\
\hline Lubrication/preparation & \\
\hline
\end{tabular}


Table 5.Frequency Scale.

\begin{tabular}{|l|c|}
\hline \multicolumn{1}{|c|}{$\begin{array}{c}\text { Worker hours per } \\
\text { incident }\end{array}$} & $\begin{array}{c}\text { Frequency } \\
\text { score }\end{array}$ \\
\hline$>100$ million & 1 \\
\hline $10-100$ million & 2 \\
\hline $1-10$ million & 3 \\
\hline $100,000-1$ million & 4 \\
\hline $10,000-100,000$ & 6 \\
\hline $1000-10,000$ & 7 \\
\hline $100-1000$ & 8 \\
\hline $10-100$ & 9 \\
\hline $1-10$ & 10 \\
\hline $0.1-1$ & \\
\hline
\end{tabular}

395

396

397

Table 6. Severity Scale

\begin{tabular}{|l|c|}
\hline Subjective severity level & Severity score \\
\hline Negligible & 1 \\
\hline Temporary discomfort & 2 \\
\hline Persistent discomfort & 8 \\
\hline Temporary pain & 16 \\
\hline Persistent pain & 32 \\
\hline Minor first aid & 64 \\
\hline Major first aid & 128 \\
\hline Medical case & 256 \\
\hline Lost work time & 1,024 \\
\hline Permanent disablement & 26,214 \\
\hline Fatality
\end{tabular}


Table 7. Consensus of experts

\begin{tabular}{|c|c|}
\hline \multicolumn{2}{|c|}{ Absolute deviation from the median } \\
\hline Frequency ratings & Severity ratings \\
\hline 0.89 & 0.91 \\
\hline
\end{tabular}

401

Table 8. Risk Scores

\begin{tabular}{|c|c|c|c|c|c|c|c|c|c|c|}
\hline & $\begin{array}{l}\text { Exposure } \\
\text { to harmful } \\
\text { substances }\end{array}$ & $\begin{array}{l}\text { Fall to } \\
\text { lower } \\
\text { level }\end{array}$ & $\begin{array}{l}\text { Fall on } \\
\text { same level }\end{array}$ & Cutting & Overexertion & $\begin{array}{l}\text { Struck } \\
\text { against } \\
\text { object in } \\
\text { motion }\end{array}$ & $\begin{array}{l}\text { Struck } \\
\text { against } \\
\text { objects }\end{array}$ & Caught-in & $\begin{array}{l}\text { Repetitive } \\
\text { motion }\end{array}$ & Others \\
\hline $\begin{array}{l}\text { Ascend /descend } \\
\text { ladder }\end{array}$ & $2.73 \cdot 10^{-8}$ & $1.86 \cdot 10^{-2}$ & $1.45 \cdot 10^{-7}$ & $2.91 \cdot 10^{-6}$ & $2.91 \cdot 10^{-5}$ & $2.91 \cdot 10^{-7}$ & $2.91 \cdot 10^{-5}$ & $5.82 \cdot 10^{-7}$ & $2.91 \cdot 10^{-5}$ & $1.00 \cdot 10^{-8}$ \\
\hline $\begin{array}{l}\text { Lift /lower } \\
\text { materials }\end{array}$ & $1.50 \cdot 10^{-8}$ & $1.86 \cdot 10^{-4}$ & $2.91 \cdot 10^{-6}$ & $1.45 \cdot 10^{-5}$ & $2.91 \cdot 10^{-5}$ & $7.27 \cdot 10^{-8}$ & $1.45 \cdot 10^{-5}$ & $1.16 \mathrm{E}-03$ & $7.27 \cdot 10^{-6}$ & $1.00 \cdot 10^{-8}$ \\
\hline Nail/screw/drill & $2.00 \cdot 10^{-8}$ & $4.65 \cdot 10^{-3}$ & $1.45 \cdot 10^{-6}$ & $5.82 \cdot 10^{-4}$ & $2.91 \cdot 10^{-3}$ & $3.20 \cdot 10^{-7}$ & $1.45 \cdot 10^{-5}$ & $5.82 \cdot 10^{-6}$ & $1.45 \cdot 10^{-3}$ & $1.00 \cdot 10^{-8}$ \\
\hline $\begin{array}{l}\text { Hammer } \\
\text { materials }\end{array}$ & $1.50 \cdot 10^{-8}$ & $4.65 \cdot 10^{-4}$ & $2.91 \cdot 10^{-6}$ & $2.91 \cdot 10^{-4}$ & $2.91 \cdot 10^{-4}$ & $3.20 \cdot 10^{-7}$ & $1.45 \cdot 10^{-4}$ & $5.82 \cdot 10^{-6}$ & $1.45 \cdot 10^{-3}$ & $1.00 \cdot 10^{-8}$ \\
\hline $\begin{array}{l}\text { Crane materials } \\
\text { and motorized } \\
\text { transport }\end{array}$ & $1.50 \cdot 10^{-8}$ & $1.86 \cdot 10^{-2}$ & $2.91 \cdot 10^{-5}$ & $2.91 \cdot 10^{-5}$ & $7.27 \cdot 10^{-8}$ & $5.82 \cdot 10^{-4}$ & $7.27 \cdot 10^{-8}$ & $1.16 \cdot 10^{-4}$ & $7.27 \cdot 10^{-7}$ & $1.00 \cdot 10^{-8}$ \\
\hline Cut materials & $1.00 \cdot 10^{-8}$ & $1.16 \cdot 10^{-5}$ & $2.91 \cdot 10^{-6}$ & $5.82 \cdot 10^{-2}$ & $2.91 \cdot 10^{-4}$ & $3.20 \cdot 10^{-7}$ & $1.4510^{-6}$ & $2.91 \cdot 10^{-7}$ & $7.27 \cdot 10^{-7}$ & $1.00 \cdot 10^{-8}$ \\
\hline Inspect/plan & $1.00 \cdot 10^{-8}$ & $1.86 \cdot 10^{-4}$ & $1.45 \cdot 10^{-6}$ & $2.00 \cdot 10^{-8}$ & $3.64 \cdot 10^{-8}$ & $2.91 \cdot 10^{-7}$ & $7.27 \cdot 10^{-7}$ & $4.00 \cdot 10^{-8}$ & $7.27 \cdot 10^{-8}$ & $1.00 \cdot 10^{-8}$ \\
\hline Manual transport & $1.00 \cdot 10^{-8}$ & $4.65 \cdot 10^{-4}$ & $7.27 \cdot 10^{-8}$ & $2.91 \cdot 10^{-7}$ & $2.91 \cdot 10^{-3}$ & $5.82 \cdot 10^{-7}$ & $2.91 \cdot 10^{-5}$ & $2.91 \cdot 10^{-7}$ & $2.91 \cdot 10^{-4}$ & $1.00 \cdot 10^{-8}$ \\
\hline Static lift & $1.00 \cdot 10^{-8}$ & $1.86 \cdot 10^{-5}$ & $7.27 \cdot 10^{-8}$ & $2.91 \cdot 10^{-5}$ & $2.91 \cdot 10^{-4}$ & $1.45 \cdot 10^{-7}$ & $1.45 \cdot 10^{-5}$ & $2.91 \cdot 10^{-7}$ & $2.91 \cdot 10^{-4}$ & $1.00 \cdot 10^{-8}$ \\
\hline $\begin{array}{l}\text { Plumb/level } \\
\text { forms }\end{array}$ & $1.82 \cdot 10^{-8}$ & $4.77 \cdot 10^{-1}$ & $2.91 \cdot 10^{-7}$ & $2.91 \cdot 10^{-6}$ & $5.82 \cdot 10^{-4}$ & $5.82 \cdot 10^{-6}$ & $1.45 \cdot 10^{-5}$ & $5.82 \cdot 10^{-7}$ & $2.91 \cdot 10^{-6}$ & $1.00 \cdot 10^{-8}$ \\
\hline Excavation & $1.00 \cdot 10^{-8}$ & $4.65 \cdot 10^{-3}$ & $5.82 \cdot 10^{-6}$ & $1.45 \cdot 10^{-7}$ & $2.91 \cdot 10^{-6}$ & $2.91 \cdot 10^{-6}$ & $1.45 \cdot 10^{-6}$ & $2.33 \cdot 10^{-5}$ & $7.27 \cdot 10^{-7}$ & $1.00 \cdot 10^{-8}$ \\
\hline $\begin{array}{l}\text { Lubrication/prep } \\
\text { aration }\end{array}$ & $3.64 \cdot 10^{-8}$ & $1.86 \cdot 10^{-4}$ & $2.91 \cdot 10^{-6}$ & $2.91 \cdot 10^{-6}$ & $5.82 \cdot 10^{-4}$ & $5.82 \cdot 10^{-6}$ & $1.45 \cdot 10^{-5}$ & $1.16 \cdot 10^{-6}$ & $2.91 \cdot 10^{-5}$ & $1.00 \cdot 10^{-8}$ \\
\hline
\end{tabular}


Table 9. Comparison of activity risk values

\begin{tabular}{|l|r|}
\hline $\begin{array}{l}\text { Vertical Formwork civil } \\
\text { construction activities }\end{array}$ & $\begin{array}{l}\text { Risk score } \\
\text { [S/w-h] }\end{array}$ \\
\hline Plumb/level forms & 0.4772 \\
\hline Cut material & 0.0585 \\
\hline Crane-lift material & 0.0194 \\
\hline Ascend/descend ladder & 0.0187 \\
\hline Nail/screw/drill & 0.0096 \\
\hline Excavation & 0.0047 \\
\hline Lift/lowe rmaterials & 0.0037 \\
\hline Hammer materials & 0.0027 \\
\hline Staticlift & 0.0014 \\
\hline Lubrication/preparation & 0.0008 \\
\hline Manual transport & 0.0006 \\
\hline Inspect/plan & 0.0002 \\
\hline TOTAL & 0.5976 \\
\hline
\end{tabular}

410

411

412

413

414

415

416

417

418 
419 Table 10.Comparison of safety risk values.

\begin{tabular}{|l|r|}
\hline Safety risk & \multicolumn{1}{|l|}{$\begin{array}{l}\text { Risk Score } \\
\text { [S/w-h }]\end{array}$} \\
\hline Fall to lower level & 0.5247 \\
\hline Cutting & 0.0591 \\
\hline Overexertion & 0.0079 \\
\hline Repetitivemotion & 0.0036 \\
\hline Caught-in & 0.0013 \\
\hline $\begin{array}{l}\text { Struck against } \\
\text { object in motion }\end{array}$ & 0.0006 \\
\hline Struckagainstobjects & 0.0003 \\
\hline $\begin{array}{l}\text { Fall on the same } \\
\text { level }\end{array}$ & 0.0001 \\
\hline $\begin{array}{l}\text { Exposure to harmful } \\
\text { substances }\end{array}$ & 0.0000 \\
\hline Others & 0.0000 \\
\hline TOTAL & 0.5976 \\
\hline
\end{tabular}

420

421

422

423

424

425

426

427

428 
Table 11. Activities description by images.

Activity name




Crane materials and

Lopez-Arquillos, A; Rubio-Romero, JC; Gibb, AGF; Gambatese, JA (2014) Safety risk assessment for vertical concrete formwork activities in civil engineering construction, Work: A Journal of Prevention, Assessment \& Rehabilitation, 49:2, 183-192, ISSN 1051-9815, DOI 10.3233/WOR-131724 


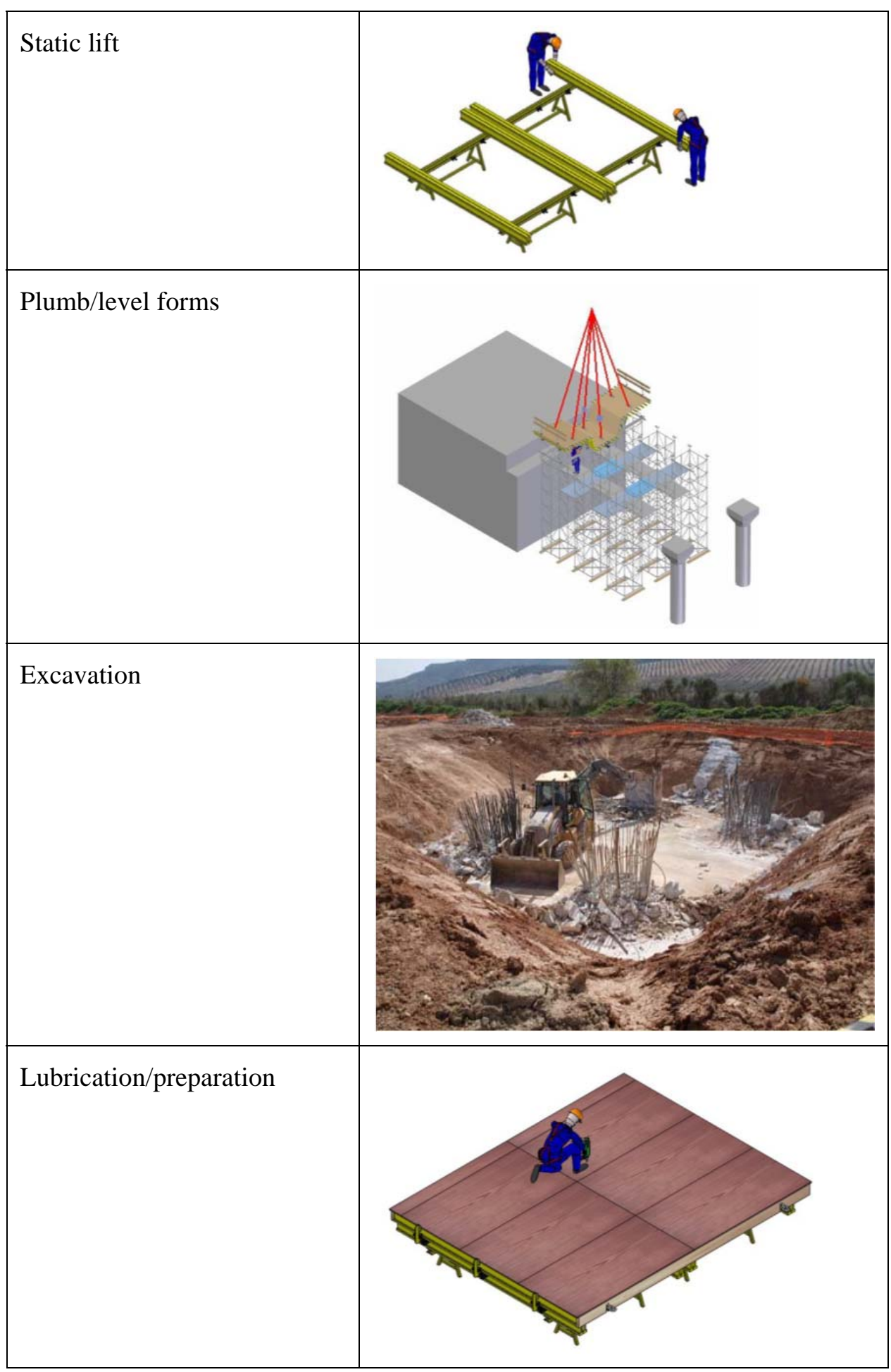

